\title{
Kesulitan Siswa Memahami Pereaksi Pembatas Di SMA Kabupaten Barito Utara Dan Kota Palangka Raya Tahun Pelajaran 2015/ 2016
}

\author{
Siti Hayati ${ }^{*}$, Suandi Sidauruk ${ }^{2}$, Abudarin ${ }^{2}$ \\ ${ }^{1}$ SMA Negeri 2 Muara Teweh, Kalimantan Tengah, Indonesia \\ ${ }^{2}$ Pendidikan Kimia, Pasca Sarjana, Universitas Palangka Raya, Indonesia
}

\begin{abstract}
Abstrak : Penelitian ini bertujuan untuk mengidentifikasikan dan menjelaskan kesulitan siswa kelas XI IPA SMA di Kabupaten Barito Utara dan Kota Palangka Raya dalam memahami konsep pereaksi pembatas, meliputi: (a) menentukan pereaksi pembatas dalam suatu pereaksi, jika gambar semua pereaksi dalam bentuk unsur dan molekul gas; (b) menentukan pereaksi pembatas dalam suatu reaksi, jika gambar semua pereaksi dalam molekul gas; (c) menentukan pereaksi pembatas dalam suatu reaksi, jika diketahui mol dari masing-masing pereaksi; (d) menentukan pereaksi dalam suatu reaksi; jika diketahui massa dari masing-masing pereaksi.Populasi penelitian adalah siswa kelas XI IPA SMA Negeri di Kabupaten Barito Utara dan Kota Palangka Raya dengan sampel penelitian sebanyak 367 siswa. Kesulitan siswa diteliti dengan menggunakan instrumen tes pemahaman konsep pereaksi pembatas (TPKPP) disertai wawancara untuk menelusuri kesulitan yang dialami siswa. Instrumem yang digunakan untuk mengukur pemahaman siswa pada level makroskopis dan level mikroskopis adalah tes tertulis dilengkapi empat pilihan jawaban dan empat pilihan alasan.Validitas isi diuji oleh empat orang ahli. Rata-rata tingkat kesukaran 0.42 dan daya beda 0,49. Reliabilitas tes dihitung dengan menggunakan Alpha Cronbach's.Hasil penelitian menunjukkan bahwa setiap indikator siswa mengalami kesulitan memahami konsep pereaksi pembatas ditinjau dari level makroskopis rata-rata sebesar 67,24\% siswa. Ditinjau dari level mikroskopis ratarata sebesar 49,33 \% siswa. Artinya tingkat kesulitan level makroskopis lebih tinggi dari tingkat kesulitan level mikroskopis. Kesulitan pada level makroskopis yang teridentifikasi adalah siswa mengalami kesulitan dalam mengkonversikan volum, massa kedalam satuan mol. Kesulitan pada level mikroskopis yang teridentifikasi adalah siswa mengalami kesulitan dalam memahami gambaran mikroskopis sehingga dalam menyelesaikan soal siswa cenderung mililih pilihan jawaban sesuai kunci tetapi salah dalam memilih alasan.Pada penelitian ini teridentifikasi empat penyebab kesulitan siswa SMA dalam memahami konsep pereaksi pembatas yaitu siswa menganggap pereaksi pembatas adalah: (a) pereaksi yang mempunyai koefisien kecil; (b) pereaksi yang mempunyai koefisien besar; (c) pereaksi yang mempunyai mol kecil; (d) pereaksi yang mempunyai massa lebih kecil.
\end{abstract}

Kata Kunci: Kesulitan, Level Representasi, Level Makroskopis, Mikroskopis, Pereaksi Pembatas 


\section{Pendahuluan}

Pembelajaran ilmu kimia merupakan bagian dari pembelajaran ilmu Pengetahuan Alam (IPA) yang merupakan konsep-konsep yang berjenjang, berkembang dari konsep-konsep yang sederhana menuju konsep-konsep yang lebih kompleks. Pembelajaran kimia di SMA merupakan kerangka dasar proses pemahaman siswa tentang ilmu kimia.

Middlecamp \& Kean (1985) menyatakan bahwa ilmu kimia memiliki beberapa karakteristik yang khas, antara lain: (1) sebagian besar materi kimia bersifat abstrak, yaitu konsep yang termasuk pada tataran mikroskopis (seperti atom, molekul, elektron dan ikatan kimia), untuk memahami konsep mikroskopis dapat dipelajari melalui gambar. Penggambaran bukan dimaksudkan untuk memberikan gambaran obyek yang sebenarnya, melainkan mencoba menekankan ciri-ciri khusus dari obyek-obyek yang bersifat abstrak; (2) ilmu kimia merupakan penyederhanaan dari yang sebenarnya; (3) materi kimia tidak hanya sekedar memecahkan soal-soalsecara konsep matematis, melainkan harus mempelajari diskripsi kimia, peristilahan khusus dan aturan-aturan kimia.

Beberapa hasil penelitian (Nakleh, 1992; Sidauruk, 1995; Kirna, 2003; Redhana, 2009; Ozmen, 2010) menunjukkan bahwa kesulitan siswa dalam belajar kimia secara bermakna disebabkan oleh rendahnya kualitas pemahaman terhadap konsep dasar kimia, seperti; konsep partikel materi, atom, molekul, ion, unsur, senyawa, campuran, larutan, dan perubahan kimia (reaksi kimia). Pereaksi pembatas mempelajari tentang konsep konkrit dan abstrak. Konsep konkrit berupa pengetahuan matematis yang berada pada level makroskopis dan konsep abstrak berupa pengetahuan non matematis yang berada pada level simbolis dan mikroskopis sehingga siswa mengalami kesulitan memahami konsep pereaksi pembatas. Pereaksi pembatas dapat ditentukan dengan cara membagi mol masing-masing zat pereaksi dengan koefesien reaksinya. Zat yang memiliki jumlah hasil bagi terkecil akan bertindak sebagai perekasi pembatas ( Sidauruk, 2005).

Standar Kompetensi Lulusan Satuan Pendidikan Menengah (SMA) bertujuan: meningkatkan kecerdasan, pengetahuan, kepribadian, akhlak mulia, serta keterampilan untuk hidup mandiri dan mengikuti pendidikan lebih lanjut (Permendiknas No. 23 Tahun 2006). Artinya, proses pembelajaran di SMA diharapkan dapat meningkatkan kompetensi sikap, pengetahuan dan keterampilan. Kompetensi pengetahuan mencakup pengetahuan non matematis dan pengetahuan matematis. Pengetahuan non matematis termasuk konsep abstrak yang berada pada level simbolis, level mikroskopis, dan konsep konkrit berada pada level makroskopis. SKL ( Standar Kompetensi Lulusan) mata pelajaran kimia ada delapan Standar Kompetensi yang harus dicapai. Satu dari kompetensi tersebut adalah menerapkan hukum-hukum dasar kimia untuk memecahkan masalah dalam perhitungan kimia. Mata pelajaran Ujian Nasional untuk jurusan 
IPA mencakup Bahasa Indonesia, Bahasa Inggris, Matematika, Fisika, Biologi, dan Kimia (BNSP, 2014). Artinya, mata pelajaran kimia merupakan salah satu mata pelajaran yang harus dipelajari siswa supaya dapat lulus Ujian Nasional.

Salah satu standar kompetensi kimia yang diajar di kelas $\mathrm{X}$ adalah memahami hukum-hukum dasar kimia dan penerapannya dalam perhitungan kimia. Materi pereaksi pembatas teridri dari dua konsep yaitu konsep konkrit dan konsep abstrak. Konsep ini tidak bisa diajarkan dengan metode ceramah. Konsep yang berifat abstrak membutuhkan penjelasan pada level mikroskopis. Level mikroskopis tidak dapat dipisahkan dari dua level lainnya yaitu level simbolis dan level makroskopis karena mengandung informasi yang saling terkait. Pentingnya peranan tiga level pada proses pembelajarn di SMA supaya guru tidak cenderung menggunakan metode ceramah, sehingga materi yang bersipat abstrak sering diabaikan.

Pokok bahasan mata pelajaran kimia di SMA ada 13. Jumlah butir soal kimia yang diujikan dalam Ujian Nasional sebanyak 40 soal. Jika butir ini tersebar pada setiap pokok bahasan maka setiap pokok bahasan minimal diwakili oleh 3 butir soal. Berdasarkan analisis terhadap lembar soal Ujian Nasional lima tahun terakhir, sebaran butir soal pada pokok bahasan stoikiometri rata-rata tiga butir soal/tahun, untuk materi pereaksi pembatas ada satu butir soal (33\%). Artinya, materi pereaksi pembatas merupakan topik yang diperlukan untuk mempelajari pokok bahasan stoikiometri. Berikut ini adalah salah satu contoh soal tentang pereaksi pembatas dalam Ujian Nasional (2014) sebagaimana ditunjukkan pada Gambar 1 berikut:

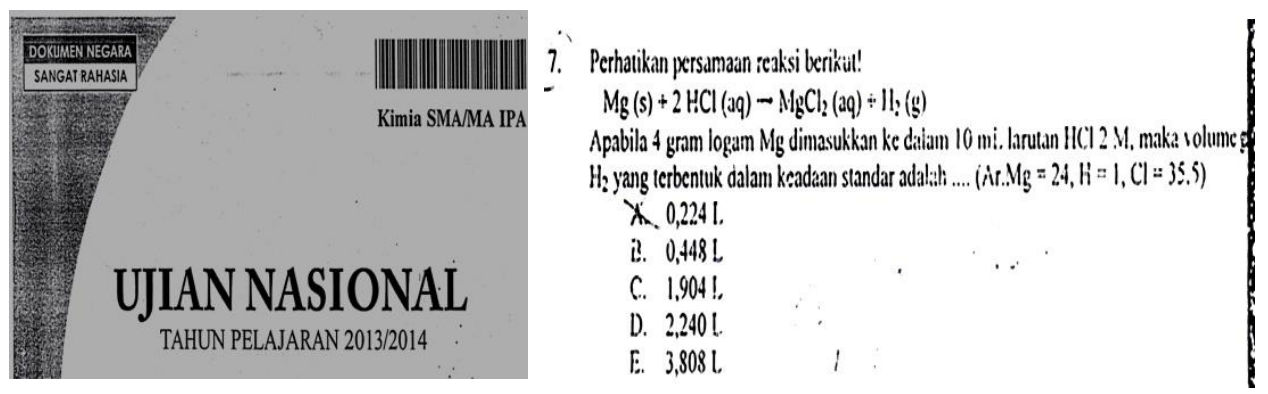

\section{Gambar 1. Soal Ujian Nasional Kimia Tahun 2013/2014}

Menurut Badan Nasional Standar Pendidikan, BNSP (2014) nilai rata-rata standar kelulusan untuk enam mata pelajaran termasuk ilmu kimia sebesar 5.5. Hasil Ujian Nasional Tahun Pelajaran 2013/2014 untuk mata pelajaran kimia pada SMAN 1 Muara Teweh nilai rata-rata 4.17. Artinya, hasil ujian nasional untuk mata pelajaran kimia di sekolah ini berada di bawah nilai rata-rata yang ditetapkan oleh BNSP. Data ini menjelaskan bahwa sebagian besar siswa di sekolah tersebut mengalami kesulitan dalam mata pelajaran kimia, termasuk materi pereaksi pembatas. Berikut adalah nilai Ujian Nasional tahun 2014 ditunjukkan pada gambar 2 berikut: 


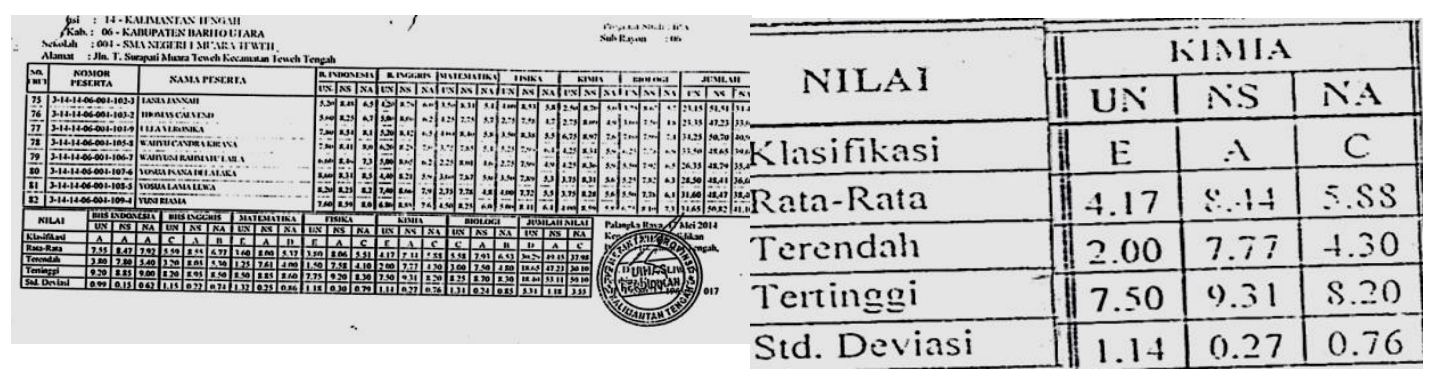

Gambar 2. Nilai Ujian Nasional Mata Pelajaran Kimia

Hasil Ujian Nasional yang menyatakan sebagian besar siswa mengalami kesulitan memahami ilmu kimia di atas di dukung oleh hasil ulangan harian siswa SMA Negeri 1 Muara Teweh kelas XA pada materi pereaksi pembatas pada indikator menentukan pereaksi pembatas seperti Gambar 3.

Pola Jawaban Salah Siswa

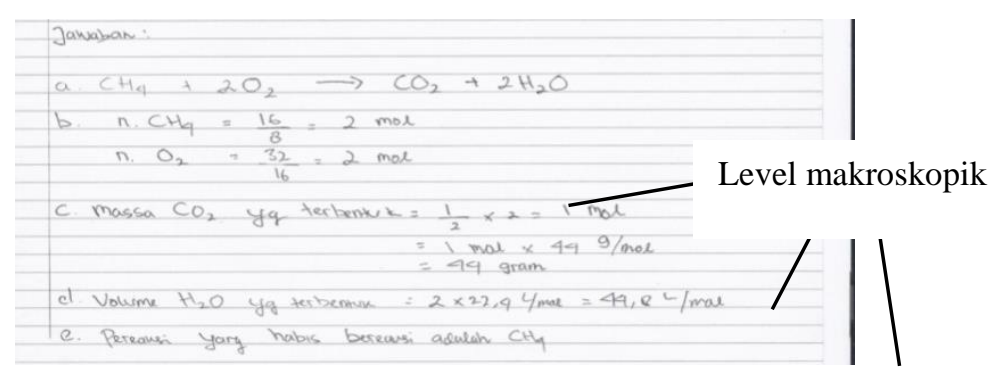

Gambar 3a

Jawaban salah siswa Gambar 3 terlihat bahwa siswa beranggapan pereaksi pembatas adalah pereaksi yang memiliki koefesien terkecil. Selain itu tidak mampu menentukan massa dan volume zat yang terbentuk. Kesalahan ini terdapat pada level makroskopis. Artinya terletak pada pengetahuan matematis. Pada siswa kelas X semester ganjil, dimana $75 \%$ nilai siswa tidak mencapai KKM yang berlaku di sekolah tersebut, hal membuktikan bahwa siswa mengalami kesulitan dalam menentukan pereaksi pembatas.

\section{A. Indentifikasi Masalah}

Materi pereaksi pembatas teridri dari dua konsep yaitu konsep konkrit dan konsep abstrak. Konsep ini tidak bisa diajarkan dengan metode ceramah. Konsep yang berifat abstrak membutuhkan penjelasan pada level mikroskopis. Level mikroskopis tidak dapat dipisahkan dari dua level lainnya karena mengandung informasi yang saling terkait. Pentingnya peranan tiga level pada proses pembelajarn di SMA supaya guru tidak cenderung menggunakan metode ceramah, sehingga materi yang bersipat abstrak sering diabaikan. 
Berdasarkan uraian di atas, dapat diidentifikasi masalah terkait dengan kesulitan siswa dalam memahami konsep pereaksi pembatas, yaitu:

(1) Sebagian besar siswa SMA mengalami kesulitan dalam menentukan pereaksi pembatas.

(2) Apakah karakteristikmateri kimia yang bersifat mikroskopis dan makroskopismerupakan salah satu faktor penyebab kesulitan.

(3) Pemahaman pada level mikrokopis dan makroskopis yang tidak terintegrasi menjadi penyebab kesulitan siswa.

\section{B. Batasan Masalah}

Sejak kurikulum 2006 pendidikan kimia di Indonesia berorientasi pada proses, yaitu siswa belajar seperti para ilmuwan, seperti melakukan percobaan di laboratorium. Untuk mendukung keberhasilan pembelajaran ini, pemerintah telah melakukan berbagai upaya antara lain, menyediakan laboratorium kimia di SMA, dan meningkatkan pengetahuan guru kimia serta kemampuan melaksanakan kegiatan keterampilan proses di kelas melalui serangkaian pendidikan dan pelatihan. Upaya ini berhasil meningkatkan pengetahuan dan keterampilan guru, namun tidak diikuti oleh penigkatan penguasaan materi kimia oleh siswa .Kendala utama yang dihadapi siswa SMA dalam mempelajari kimia adalah mata pelajaran kimia pertama kali diajarkan di SMA dan sebagian besar konsep penyusun bersipat abstrak. Kedua faktor ini berpotensi menyebabkan kesulitan siswa dalam memahami konsep kimia.

Materi pereaksi pembatas yang berada pada level simbolis, mikroskopis, dan makroskopik. Ketiga faktor ini berpotensi sebagai penyebab kesulitan siswa dalam memahami konsep pereaksi pembatas. Oleh karena itu rendah pemahaman siswa terhadap pemahaman konsep pereaaksi pembatas disebabkan oleh kesulitan dalam memahami level simbolis, yang berhubungan dengan simbol seperti gambar atom, lambing unsur dan rumus kimia. Level mikroskopis adalah level kimia yang nyata tapi masih memerlukan pemahaman seperti atom, molekul, elektron dan ikatan kimia. Level makroskopis adalah sesuatu yang nyata seperti hitungan kimia. Konsep perekasi pembatas mencakup mendefinisikankan pereaksi pembatas dan menentukan zat yang menjadi pereaksi pembatas.

\section{Rumusan Masalah}

Berdasarkan batasan masalah di atas, maka masalah dalam penelitian ini adalah: Bagaimana menjelaskan kesulitan siswa SMA Negeri kelas X di Kabupaten Barito Utara dan di Kota Palangka Raya dalam memahami konsep pereaksi pembatas ditinjau dari level simbolis, mikroskopis, dan makroskopis.

\section{Tujuan Penelitian}


Tujuan penelitian ini untuk mendeskripsikan kesulitan siswa SMA kelas X dalam memahami konsep pereaksi pembatas ditinjau dari tingkat simbolis, mikroskopis, dan makroskipis.

\section{E. Manfaat Penelitian}

Manfaat dalam penelitian ini ada dua yaitu:

1. Manfaat teoritis dalam penelitian ini adalah Penelitian ini diharapkan dapat memperkaya kajian tentang kesulitan memahami ilmu kimia khususnya konsep pereaksi pembatas di SMA. Penelitian mengenai kesulitan siswa pokok bahasan stoikiometri dalam menentukan pereaksi pembatas belum pernah dilakukan di Kabupaten Barito Utara dan kota Palangka Raya.

2. Manfaat Praktis dalam penelitian ini yaitu :

- Memberikan informasi kepada guru-guru kimia, khususnya guru kimia kelas X SMA Negeri di Kabupaten Barito Utara dan di Kota Palangka Raya tentang kesulitan siswa dalam menentukan pereaksi pembatas.

- Memberikan gambaran kepada siswa tentang letak kesulitan dalam menentukan pereaksi pembatas saat mengerjakan tes.

\section{Metodologi Penelitian}

\section{A. Tempat dan Waktu Penelitian}

Penelitian ini dilaksanakan di SMA Negeri Kabupaten Barito Utara

Dan Kota Palangka Raya pada semester genap tahun ajaran 2015/2016.

\section{Populasi dan Sampel Penelitian}

\subsection{Populasi Penelitian}

Populasi dalam penelitian ini adalah siswa kelas XI IPA SMA di Kabupaten Barito Utara dan Kota Palangka Raya Tahun Pelajaran 2015/2016 yang telah menerima materi pelajaran pereaksi pembatas. Populasi adalah seluruh siswa kelas XI IPA SMA Negeri di Kabupaten Barito Utara dan Kota Palangka Raya. Jumlah SMA Negeri di Kabupaten Barito Utara dan Kota Pangka Raya masing-masing 7 dan 10 sekolah.

\subsection{Sampel}

Jumlah SMA Negeri yang akan dilibatkan pada masing-masing wilayah penelitian sebanyak 50\% di Kabupaten Barito Utara: SMA Negeri 1 Muara Teweh, SMA Negeri 2 Muara Teweh, SMA Negeri 3 Muara Teweh, SMA Negeri 4 Muara Teweh dan 40\% Kota Palangka Raya: SMA Negeri 1 Palangka Raya, SMA Negeri 2 Palangka Raya, SMA Negeri 3 Palangka Raya, SMA Negeri 4 Palangka Raya. Jumlah siswa di Kabupaten Barito Utara dari masing-masing 
sekolah tersebut 39 siswa, 18 siswa, 14 siswa, 13 siswa dengan jumlah keseluruhan siswa 84 siswa. Kota Palangka Raya masing-masing 82 siswa, 68 siswa, 66 siswa, dan 67 siswa dengan jumlah 283. Artinya, jumlah sampel target penelitian ini sebanyak 4 sekolah yang tersebardi Kabupaten Barito Utara (4 sekolah) dan Kota Palangka Raya (4 sekolah). Jumlah siswa yang terlibat dalam penelitian ini berjumlah 367 siswa.

\section{B. Prosedur Pengumpulan dan Pengolahan Data}

Data yang diperlukan dalam penelitian ini adalah; (1) data pola jawaban siswa terhadap tes diagnosa pereaksi pembatas (TDPP) untuk digunakan mengidentifikasi butir soal yang masuk katagori sulit dan mengidentifikasi siswa yang mengalami kesulitan; (2) deskripsi kesulitan yang dimiliki siswa. Kedua konsep ini dijaring dengan menggunakan TDPP untuk mendapatkan data pola jawaban siswa, dan melakukan wawancara untuk mendapatkan diskripsi kesulitan yang dimiliki siswa.

\section{Pemberian TDPP}

Tes tertulis pemahaman konsep siswa tentang pereaksi pembatas disususn dengan ketentuan berikut:

a) TPKPP merupakan tes yang disusun dengan cakupan konsep pereaksi pembatas.

b) TPKPP berfungsi sebagai alat diagnosa kesulitan siswa memahami konsep pereaksi pembatas.

c) Bentuk TPKPP adalah pilihan ganda dengan 4 pilihan jawaban, dan pilihan alasan tertutup dengan 4 alasan.

d) Banyak soal tes adalah 10 soal dengan waktu pengerjaan (70 menit)

e) Kisi-kisi TPKPP disosialisasikan kepada siswa minimal satu hari sebelum pelaksanaan TPKPP.

f) Waktu pelaksanaan TPKPP disesuaikan dengan jadwal yang diberikan oleh sekolah.

g) Siswa mengerjakan TPKPP di dalam ruangan kelas dan guru mendampingi siswa selama pengerjaan soal tersebut

\section{Wawancara}

Wawancara digunakan unutk memeriksa ulang informasi yang diberikan oleh hasil pemberian TDPP. Sebab itu, pedoman wawancara adalah soal-soal TDPP yang masuk katagori sulit berdasarkan informasi hasil pemberian TDPP. Pelaksanaan wawancara dilakukan dengan cara: (1) memberikan kepada siswa butir soal yang masuk katagori sulit (soal sudah diketik ulang tanpa menyertakan alternatif alasan jawaban); dan (2) siswa disuruh membaca dengan cermat pern- 
yataan soal dan menjawab secara tertulis, serta alasan jawaban yang diberikan. Selanjutnya, untuk mendapatkan informasi yang lebih konprehensif pernyataan yang diajukan dalam wawancara dapat berkembang mengikuti jawaban siswa.

\section{Instrumen Penelitian}

Instrumen yang digunakan dalam penelitian ini adalah tes tertulis dan tes lisan. Tes tertulis berbentuk pilihan ganda dengan alasan tertutup. Jumlah butir soal sebanyak 10 soal. Selanjutnya tes tertulis ini disebut TPKPP (tes pemahaman konsep pereaksi pembatas). Tes lisan berbentuk wawancara diagnostik yang berpedoman pada TPKPP.

Instrumen yang digunakan dalam penelitian ini dibuat, disusun, disesuaikan cakupan konsepnya dengan Permendiknas nomor 22 tahun 2006 tentang Standar isi yang memuat kompetensi dasar pada silabus Kurikulum Tingkat Satuan Pendidikan (KTSP) Mata Pelajaran Kimia SMA kelas X, dengan indikator pemahaman konsep pereaksi pembatas seperti Tabel 3.

Tabel 3. Cakupan Indikator Pereaksi Pembatas

\begin{tabular}{|c|c|c|c|c|}
\hline $\begin{array}{c}\text { Sub } \\
\text { Konsep }\end{array}$ & Indikator & $\begin{array}{l}\text { Pernyataan } \\
\text { Pengetahuan } \\
\text { Proposional }\end{array}$ & $\begin{array}{c}\text { Level } \\
\text { Representasi }\end{array}$ & Butir soal \\
\hline $\begin{array}{l}\text { Pereaksi } \\
\text { Pembatas }\end{array}$ & $\begin{array}{l}\text { 2. Menentukan pereaksi pembatas } \\
\text { dalam suatu reaksi jika gambar } \\
\text { semua pereaksi dalam bentuk } \\
\text { molekul gas } \\
\text { 3. Menentukan pereaksi pembatas } \\
\text { dalam suatu reaksi jika diketahui } \\
\text { mol dari masing- masing pe- } \\
\text { reaksi. } \\
\text { 4. } \\
\text { Menentukan pereaksi pembatas } \\
\text { dalam suatu reaksi jika diketahui } \\
\text { massa dari masing- masing pe- } \\
\text { reaksi dalam suatu reaksi, }\end{array}$ & $\begin{array}{l}\text { Pereaksi } \\
\text { pembatas } \\
\text { adalah zat } \\
\text { yang memiliki } \\
\text { hasil } \\
\text { terkecil } \\
\text { antara mol } \\
\text { zat yang } \\
\text { tersedia } \\
\text { dengan } \\
\text { koefisien } \\
\text { zat tersebut. }\end{array}$ & mikroskopis & $2,3,4$ \\
\hline
\end{tabular}

\section{Validitas, Realibilitas, Daya Beda, dan Tingkat Kesukaran}


Sebelum tes pemahaman konsep pereaksi pembatas (TPKPP) dipergunakan untuk mengumpulkan data, maka butir soal tes divalidasi. Validitas tes merupakan ukuran yang menyatakan kesahihan suatu instrumen sehingga mampu mengukur apa yang hendak diukur. Uji validitas tes yang digunakan adalah uji validitas isi. Validitas ini digunakan untuk mengukur kesesuaian tujuan khusus dengan butir soal tes. Validasi dilakukan oleh validator yang terdiri 4 (empat) orang ahli di bidangnya.

Validasi butir soal dilakukan dengan cara konsultasi mengenai kesesuaian masing-masing butir soal, keterbacaan dan waktu yang tersedia terhadap materi yang diujikan, dengan kriteria sebagai berikut:

a) "2" apabila butir soal komunikatif dan menunjukkan kesesuaian dengan tujuan yang hendak diukur.

b) "1" apabila butir soal komunikatif tetapi tidak sesuai dengan tujuan yang hendak diukur selanjutnya dikomentari.

c) “0” apabila butir soal tidak komunikatif dan tidak sesuai dengan tujuan yang hendak diukur selanjutnya dikomentari.

Jika lebih dari 50\% validator menyatakan " 2 " maka soal dianggap memenuhi validitas isi tes, dan soal atau tes dapat diujicobakan kepada siswa.

Realibilitas diuji dengan menggunakan SPSS version 16.0., untuk mengetahui daya pembeda diantara siswa maka dilakukan perhitungan Daya Beda (DB) serta untuk mengetahui tingkat kesukaran item tes, dilakukan perhitungan tingkat kesukaran (Tk).

\section{E. Teknik Analisis Data}

Data yang diperlukan dalam penelitian ini adalah: (1) data tentang pola jawaban siswa terhadap TKPP yang digunakan untuk mengidentifikasi butir soal yang masuk katagori sulit dan mengidentifikasi siswa yang memiliki kesulitan; (2) deskripsi kesulitan pereaksi pembatas yang dimiliki siswa. Siswa yang mengerjakan benar butir soal TPKPP diberi skor (1), dan skor nol untuk jawaban salah, dan untuk siswa yang memilih pilihan jawaban ganda atau tidak memilih jawaban maka tidak ikut dianalisis. Selanjutnya ditentukan prosentase skor jawaban benar siswa.

$$
\% \text { Skor benar }=\frac{\text { Jumlah siswa yang menjawab benar }}{\text { Jumlah siswa total }} \times 100 \%
$$

Untuk mengetahui pola jawaban-alasan siswa terhadap TDKPP dianalisis mengunakan SPSS version 16.0 for Windows. Pilihan jawaban -alasan siswa yang dihasilkan dari TDPP mempunyai pola sebagai berikut: (1) pilihan jawaban pilihan alasan benar (BB); (2) pelihan jawaban benar-pilihan alasan salah (BS); (3) pilihan jawaban salah-pilihan alasan benar SB); (4) pilihan jawaban salah pilihan alasan salah (SS). Analisis pilihan jawaban-pilihan alasan didasarkan 
tingkat pengetahuan nya. Tingkat pengetahuan berdasarkan pola pasangan pilihan jawaban -pilihan alasan siswa (Tabel 7).

Tabel 4. Tabel Pengetahuan dan Pola Jawaban-Alasan

\begin{tabular}{ll}
\hline Tingkat Pengetahuan & Pola jawaban-Alasan \\
Siswa memahami (SM) & Benar-benar (BB) \\
\hline & Benar-salah (BS) \\
Siswa sulit memahami (SP) & Salah- benar (SB) \\
& Salah-salah (SS) \\
\hline
\end{tabular}

Pola di atas dikelompokan menjadi dua, yaitu: (1) siswa dapat memahami jkia mempunyai pola pilihan BB, dan (2) “ siswa sulit memaham” jika mempunyai pola pilihan B-S, S-B, dan S-S. Dari hasil tersebut ditentukan konsep yang sulit dipahami dan jumlah siswa yang sulit memahami. Kesulitan siswa dalam memahami konsep pereaksi pembatas ditelusuri dengan melakukan wawancara terhadap " siswa-sulit memahami”. Selanjutnya hasil wawancara digunakan untuk menjelaskan penyebab kesulitan tersebut.

\section{a. Uji Coba TPKPP}

Uji coba instrumen TPKPP dilakukan pada akhir bulan Desember dan bulan Januari. Tempat uji coba di SMA Negeri 1 Muara Teweh 43 siswa) dan SMA Negeri 2 Muara Teweh (40 siswa), dan SMAN 4 Palangka Raya (42 siswa). Pemilihan subyek uji coba penelitian dilakukan: pada SMA Negeri di Kabupaten Barito Utara dan Kota Palangka Raya sebagai salah satu tempat penelitian.

Data uji coba digunakan untuk mengetahui indeks daya beda soal, indeks tingkat kesukaran, efektifitas pengecoh dari TPKPP. Data yang diperoleh selanjutnya diberi pengkodean dan dianalisis menggunakan SPSS version 16.0. Analisis data uji coba untuk mengetahui tingkat kesukaran soal dan rerata daya beda soal. Pada penelitian ini ditetapkan tingkat kesukaran yang ideal sebesar 0,3-0,7 dan indeks daya beda dikatakan baik jika memiliki harga minimal 0,25 ke atas (Sidauruk, 2005). Reliabilitas dihitung dengan menggunakan SPSS dan hasilnya dibandingkan dengan 5\% r-tabel (Azwar, 2012). Analisis data hasil uji coba kemudian dikonsultasikan dengan ahlinya, diperoleh beberapa soal perlu mengalami revisi tanpa merubah maksud dari soal tersebut dan untuk mempertimbangkan konsistensi jawaban siswa maka pada level mikroskopis dan makroskopis pada masing-masing soal perlu diaflikasikan dengan menggunakan gambar. Berdasarkan hasil uji coba instrumen yang telah dikembangkan, berikut ini disajikan karakteristik tes diagnostik pemahaman konsep pereaksi pembatas. Karakteristik tes diagnostik pemahaman konsep pereaksi pembatas dapat dilihat pada tabel 8. 
Tabel 5. Karakteristik Tes Diagnostik Pemahaman Konsep Pereaksi Pembatas

\begin{tabular}{lcc}
\hline Indikator & Hasil & Keterangan \\
\hline Butir soal & 10 & - \\
Waktu pelaksanaan tes & 70 menit & - \\
Bentuk tes & Pilihan ganda & - \\
Sub konep & 1 & - \\
Tingkat kesesuainan butir soal & 2 & $0,0-0,50=$ dibuang \\
& & $0,51-1,0=$ direvisi \\
& & $1,1-2,0=$ diterima \\
Reliabilitas & 0,468 & Sedang \\
Rata-rata DB & 0,49 & Ideal \\
Rata-rata TK & 0,42 & Ideal
\end{tabular}

\section{Pembahasan}

\section{A. Pelaksanaan Penelitian}

Penelitian ini dilaksanakan di satu Kabupaten dan satu Kota yaitu Kabupaten Barito Utara (4 sekolah (50\%); SMA Negeri 1 Muara Teweh, SMA Negeri 2 Muara Teweh, SMA Negeri 3 Muara Teweh dan SMA Negeri 4 Muara Teweh) dan Kota Palangka Raya ( 4 sekolah (40\%); SMA Negeri 1 Palangka Raya, SMA Negeri 2 Palangka Raya, SMA Negeri 3 Palangka Raya dan SMA Negeri 4 Palangka Raya). Tes penguasaan konsep pereaksi pembatas melibatkan 367 siswa kelas XI IPA yang terdiri dari $83(22,60 \%)$ siswa dan Kota Palangka Raya 284 $(77,38 \%)$ siswa. Rincian sebaran siswa pada setiap sekolah dapat dilihat pada Tabel 6.

Tabel. 6 Jumlah Sebaran Siswa pada setiap sekolah

\begin{tabular}{|c|c|c|c|c|c|c|c|c|c|c|}
\hline \multirow{2}{*}{ No } & \multicolumn{4}{|c|}{$\begin{array}{l}\text { SMA Negeri Kabupat- } \\
\text { en BaritoUtara }\end{array}$} & \multirow{2}{*}{ Total } & \multicolumn{4}{|c|}{$\begin{array}{c}\text { SMA Negeri Kota } \\
\text { Palangka Raya }\end{array}$} & \multirow{2}{*}{ Total } \\
\hline & 1 & 2 & 3 & 4 & & 1 & 2 & 2 & 4 & \\
\hline $\begin{array}{l}\text { Jlh } \\
\text { Kelas }\end{array}$ & 1 & 1 & 1 & 1 & 4 & 2 & 2 & 2 & 2 & 8 \\
\hline $\begin{array}{l}\text { Jumlah Sampel } \\
\text { Penelitian }\end{array}$ & 39 & 18 & 13 & 13 & 83 & $\begin{array}{l}8 \\
2\end{array}$ & $\begin{array}{l}6 \\
8\end{array}$ & 66 & 51 & 267 \\
\hline Total & & & & & 83 & & & & & 267 \\
\hline
\end{tabular}

Siswa yang mengerjakan tes dan mengembalikan lembar jawaban sebanyak 367 lembar jawaban. Ketika dianalisis terdapat 17 (4,63\%) lembar jawaban siswa yang tidak layak dianalisis. Artinya, lembar jawaban yang layak dianalisis sebanyak 350 (95,36\%). Lembar jawaban tersebut tidak dianalisis karena terdapat $10(2,7 \%)$ siswa mempunyai jawaban ganda, dan $7(1,9 \%)$ siswa tidak memilih pilihan alasan. Waktu penelitian dilaksanakan pada semester genap tahun pelajaran 2015/2016, dimulai tanggal 6 Februari sampai tanggal 29 April 2016. 


\section{B. Deskripsi Data}

Setelah data jawaban siswa terkumpul, analisis dilakukan dengan mengelompokkan pola jawaban siswa, melakukan pengkodean.Analisis terhadap skor yang diperoleh siswa, didapat dari skor rata - rata setiap indikator butir soal. Skor rata-rata dapat dihitung dari skor rata- rata setiap butir soal. Menurut standar nasional skor ideal yaitu 75\% (BNSP,2008). Artinya, skor siswa yang berada di atas KKM nasional berarti siswa tidak mengalami kesulitan dalam menyelesaikan setiap butir soal TPKPP, sedangkan skor yang berada di bawah KKM nasional berarti siswa mengalami kesulitan dalam menyelesaikan setiap butir soal TPKPP baik secara makroskopis maupun mikroskopis. Rincian jumlah siswa memjawab benar tanpa alasan tiap butir soal dapat lihat pada Tabel 7.

Tabel 7. Rincian Jumlah Butir Soal dan Skor Rata-Rata Jawaban Benar

Tanpa Alasan

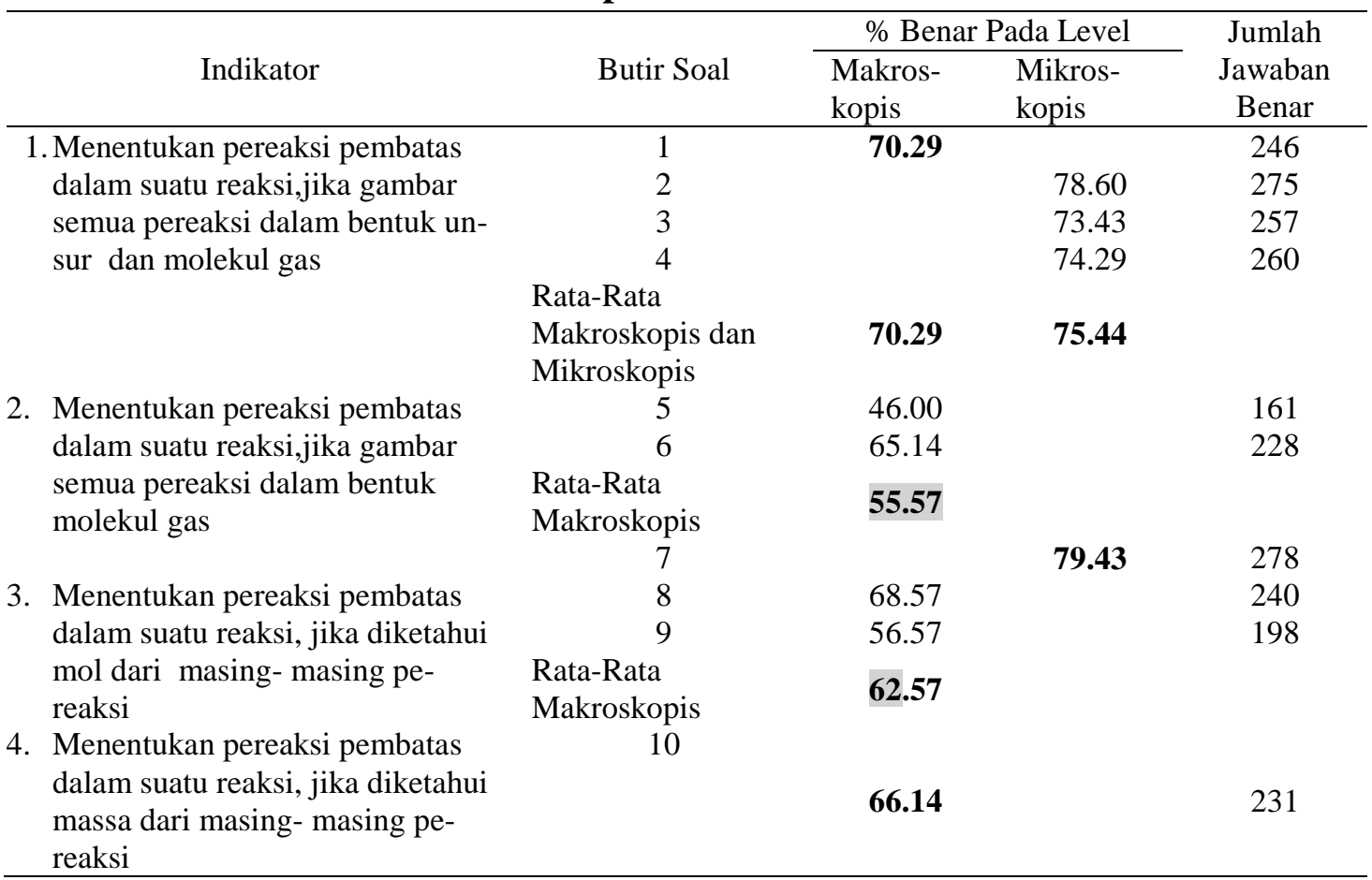

\section{Identifikasi "Butir Soal Kesulitan"}

\subsection{Analisis Pilihan Jawaban}

Identifikasi kesulitan menggunakan analisis terhadap pilihan jawaban. Analisis pilihan jawaban menggunakan data distribusi pilihan jawaban siswa terhadap TPKPP tanpa melibatkan data distribusi pilihan alasan siswa.. Distribusi pilihan jawaban siswa secara rinci seperti dalam Tabel 8 .

Tabel 8. Jumlah Siswa Menjawab Benar-tanpa Alasan, Jawaban BenarAlasan Benar, dan "Siswa-Kesulitan" pada Setiap Butir Soal.

\begin{tabular}{cccccc}
\hline Konsep & No & Level & BT $^{1)}$ & BB $^{1)}$ & $\begin{array}{c}\text { Siswa } \\
\text { Kesulitan }\end{array}$ \\
\hline
\end{tabular}




\begin{tabular}{|c|c|c|c|c|c|c|c|c|}
\hline \multirow{11}{*}{ 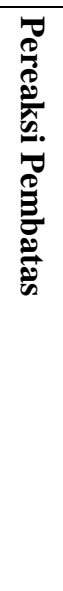 } & & & Jlh & $\%$ & Jlh & $\%$ & Jlh & $\%$ \\
\hline & 1 & Makroskopis & 246 & 70.29 & 80 & 22.86 & 270 & 77.14 \\
\hline & 2 & Mikroskopis & 275 & 78.6 & 187 & $\mathbf{5 4 . 3 0}$ & 163 & 46.57 \\
\hline & 3 & Mikroskopis & 257 & 73.43 & 147 & 42.00 & 203 & $\mathbf{5 8 . 0 0}$ \\
\hline & 4 & Makroskopis & 260 & 74.29 & 148 & 42.29 & 202 & 57.71 \\
\hline & 5 & Mikroskopis & 161 & 46.00 & 118 & 33.71 & 232 & 66.29 \\
\hline & 6 & Makroskopis & 228 & 65.14 & 150 & 42.86 & 200 & 57.14 \\
\hline & 7 & Mikroskopis & 278 & 79.43 & 194 & 55.43 & 156 & 44.57 \\
\hline & 8 & Makroskopis & 240 & 68.57 & 82 & 23.43 & 268 & 76.57 \\
\hline & 9 & Makroskopis & 198 & 56.57 & 134 & 38.29 & 216 & 61.71 \\
\hline & 10 & Makroskopis & 231 & 66.00 & 155 & 44.29 & 195 & 55.71 \\
\hline
\end{tabular}

Sebaran jumlah siswa menjawab benar dengan alasan benar pada indikator 1,2,3, dan 4 ditinjau dari level makroskopis dan level mikroskopis dapat dijelaskan menggunakan grafik 1 dan grafik 2. Menentukan pereaksi pembatas dalam suatu reaksi, jika gambar semua pereaksi dalam bentuk unsur dan molekul gas meningkat sebesar $25.33 \%$ dari level makroskopis ke level makroskopis. Menentukan pereaksi pembatas dalam suatu reaksi, jika gambar semua pereaksi dalam bentuk molekul gas. Sebaran skor siswa menjawab benar dengan alasan benar dapat dilihat pada gambar 1 .

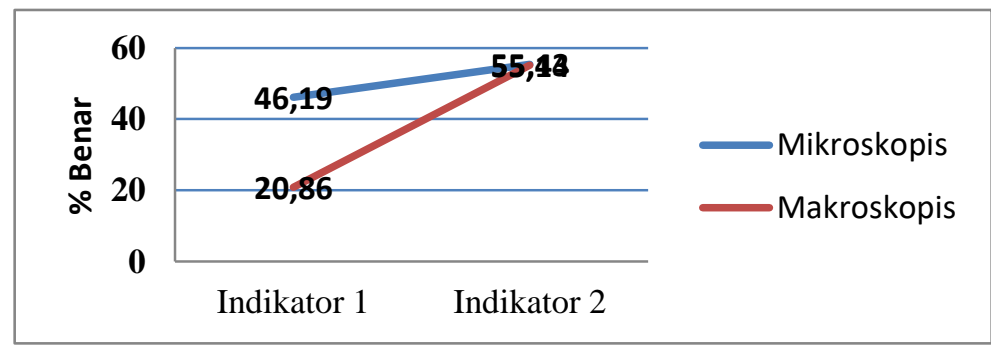

\section{Gambar 1. Grafik sebaran skor jawaban benar dan alasan benar}

Berdasarkan grafik 1 dapat disimpulkan bahwa siswa yang menjawab sesuai dengan pilihan jawaban dan pilihan alasan disebut siswa memahami. Data siswa yang memahami konsep pereaksi pembatas seperti pada tabel 11. Berdasarkan tabel 11 dapat dijelaskan jumlah siswa yang tidak dapat memilih pilihan jawaban dan pilihan alasan sesuai dengan kunci jawaban. Siswa demikian adalah siswa yang mengalami kesulitan. Data siswa yang mengalami kesulitan dapat dijelaskan dengan menggunakan gambar 2.

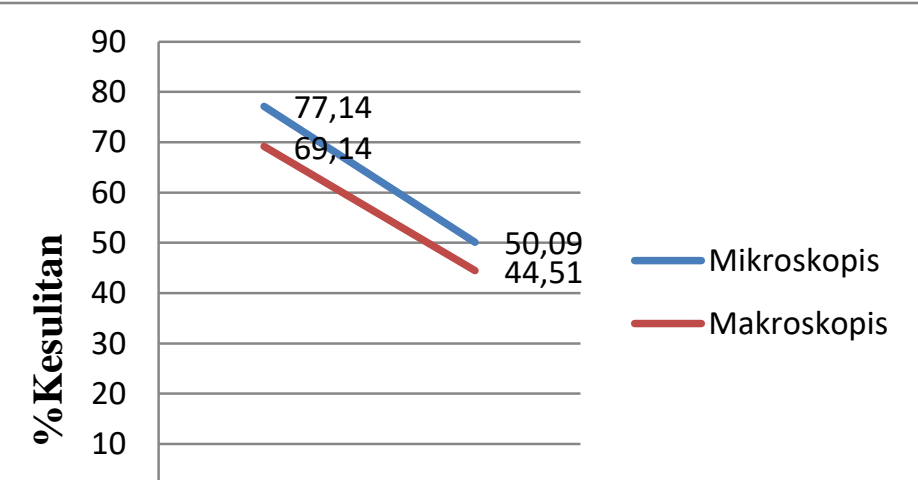


Gambar 2. Grafik sebaran skor siswa yang mengalami kesulitan

Destribusi kesulitan yang dialami siwa pada materi pereaksi pembatas ditinjau dari level makroskopis dan level mikroskopis dapat dilihat pada tabel 9.

\section{Tabel 9. Jumlah Siswa Kesulitan}

\begin{tabular}{|c|c|c|c|c|c|}
\hline \multirow[t]{2}{*}{ Indikator } & \multirow{2}{*}{$\begin{array}{c}\text { No } \\
\text { Soal }\end{array}$} & \multicolumn{2}{|c|}{ Level Makroskopis } & \multicolumn{2}{|c|}{ Level Mikroskopis } \\
\hline & & $\begin{array}{c}\text { Jumlah Kesu- } \\
\text { litan }\end{array}$ & $\begin{array}{c}\% \text { Kesu- } \\
\text { litan }\end{array}$ & $\begin{array}{c}\text { Jumlah Kesu- } \\
\text { litan }\end{array}$ & $\begin{array}{l}\% \text { Kesu- } \\
\text { litan }\end{array}$ \\
\hline \multirow[t]{4}{*}{1} & 1 & 270 & 77.14 & & \\
\hline & 2 & & & 163 & 46.57 \\
\hline & 3 & & & 203 & 58.00 \\
\hline & 4 & & & 202 & 57.71 \\
\hline \multicolumn{3}{|c|}{ Nilai rata-rata pada setiap level } & 77.14 & & 54.09 \\
\hline \multirow[t]{3}{*}{2} & 5 & 232 & 66.29 & & \\
\hline & 6 & 200 & 67.71 & & \\
\hline & 7 & & & 156 & 44.57 \\
\hline \multicolumn{3}{|c|}{ Nilai ratarata pada setiap level } & 67.00 & & \\
\hline \multirow[t]{2}{*}{3} & 8 & 268 & 76.57 & & \\
\hline & 9 & 216 & 61.71 & & \\
\hline \multicolumn{3}{|c|}{ Nilai rata-rata pada setiap level } & 69.14 & & \\
\hline 4 & 10 & 195 & 55.71 & & \\
\hline
\end{tabular}

$\mathrm{SB}=$ jika jawaban siswa salah dan alasan yang diberikan benar.

$\mathrm{SS}=$ jika jawaban siswa salah dan alasan yang diberikan salah.

\subsection{Analisis Pilihan Alasan}

Dalam mengerjakan soal TPKPP siswa menjawab sesuai dengan kunci jawaban adalah memahami yaitu; (1) siswa memilih pilihan jawaban benar (BT), siswa memilih pilihan jawaban benar dan pilihan alasan benar (BB), dan (2) siswa tidak memilih pilihan jawaban adalah siswa kesulitan yaitu; (1) siswa memilih pilihan jawaban benar dan pilihan alasan salah (BS), (2) siswa memilih pilihan jawaban salah dan pilihan alasan benar (SB), (3) siswa memilih pilihan jawaban salah dan pilihan alasan salah (SS). Analisis pilihan alasan menggunakan data distribusi pilihan alasan siswa terhadap TPKPP tanpa melibatkan data distribusi pilihan jawaban siswa. 


\subsection{Identifikasi "Siswa Kesulitan"}

Identifikasi "siswa-kesulitan" didasarkan tingkat pengetahuannya. Tingkat pengetahuan ditentukan berdasarkan pola pasangan jawaban-alasan siswa terhadap TPKPP. Pola pasangan jawaban-alasan siswa dikelompokkan menjadi empat: yaitu (1) jawaban benar-alasan benar; (2) jawaban benar-alasan salah; 3) jawaban salah-alasan benar; (4) jawaban salah-alasan salah. Berdasarkan pengelompokan pasangan jawaban-alasan tersebut, siswa dikategorikan menjadi (a) "siswa memahami" jika termasuk kelompok (1) dan (b) "siswa kesulitan" jika termasuk kelompok (2), (3), dan (4). Siswa kesulitan didasarkan pada tingkat pengetahuan. Tingkat pengetahuan ditentukan berdasarkan pola pasangan jawaban-alasan siswa terhadap tes diagnosa pemahaman konsep pereaksi pembatas (TPKPP).Sebaran pola jawaban -alasan terdapat dalam Tabel 11.

Tabel 11. Rincian Jumlah Siswa Menjawab Benar - Tanpa Alasan, Jawaban Benar-Alasan Benar, Jawaban Benar- Alasan Salah, Jawaban Salah- Alasan Benar, dan Jawaban Salah - Alasan Salah

\begin{tabular}{|c|c|c|c|c|c|c|c|c|c|c|c|}
\hline \multirow[t]{2}{*}{ 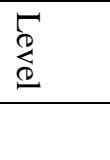 } & \multirow{2}{*}{ 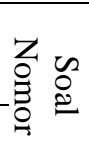 } & \multicolumn{4}{|c|}{$\begin{array}{c}\text { Siswa } \\
\text { Memahami }\end{array}$} & \multicolumn{6}{|c|}{ Jumlah Siswa Kesulitan } \\
\hline & & $\mathrm{BT}$ & $\% \mathrm{BT}$ & $\mathrm{BB}$ & $\% \mathrm{BB}$ & BS & $\% \mathrm{BS}$ & SB & $\% \mathrm{SB}$ & SS & $\% \mathrm{SS}$ \\
\hline Mikro & 1 & 246 & 70.29 & 80 & 22.86 & 166 & 47.5 & 29 & 8.29 & 75 & 21.43 \\
\hline Makro & 2 & 275 & 78.57 & 187 & 53.43 & 88 & 24.50 & 36 & 10,29 & 39 & 14.14 \\
\hline Mikro & 3 & 257 & 73.43 & 147 & 42.00 & 110 & 31.43 & 27 & 7.71 & 66 & 18.86 \\
\hline Makro & 4 & 260 & 74.29 & 148 & 42.29 & 112 & 32.00 & 26 & 7.43 & 64 & 18.29 \\
\hline Mikro & 5 & 161 & 46.00 & 118 & 33.71 & 43 & 12.29 & 42 & 12.00 & 147 & 42.00 \\
\hline Makro & 6 & 228 & 65.14 & 150 & 42.86 & 78 & 22.29 & 37 & 10.57 & 85 & 24.28 \\
\hline Mikro & 7 & 278 & 79.43 & 194 & 55.43 & 84 & 24.00 & 27 & 7.71 & 45 & 12.8 \\
\hline Makro & 8 & 240 & 68.57 & 82 & 23.43 & 158 & 45.14 & 31 & 8.86 & 79 & 22.57 \\
\hline Makro & 9 & 198 & 56.57 & 134 & 38.29 & 64 & 18.29 & 50 & 14.29 & 102 & 29.14 \\
\hline Makro & 10 & 231 & 44.29 & 155 & 44.29 & 76 & 21.71 & 45 & 12.86 & 74 & 21.14 \\
\hline
\end{tabular}

Keterangan:

BT = jika jawaban siswa benar dan tanpa alasan

$\mathrm{BB}=$ jika jawaban siswa benar dan alasan yang diberikan benar.

$\mathrm{BS}=$ jika jawaban siswa benar dan alasan yang diberikan salah.

SB = jika jawaban siswa salah dan alasan yang diberikan benar.

SS = jika jawaban siswa salah dan alasan yang diberikan salah

\section{Deskripsi Kesulitan yang Terjadi Pada Siswa}

Kesulitan yang terjadi pada siswa adalah ketidakmampuan memilih jawaban benar dengan pilihan alasan benar. Data pada tabel di bawah ini menjelaskan jumlah siswa yang memilih jawaban benar tanpa alasan (BT) ${ }^{1}$ prosentasenya telah berkurang menjadi $(\mathrm{BB})^{1}$, yang artinya siswa memilih menjawab jawaban benar dengan pilihan alasan benar. Berkurangnya (BT) ${ }^{1}$ 
Jurnal Ilmiah Kanderang Tingang 9(2) (2018) 114-132 ISSN 2087-166X

Januari-Juni 2018
Fakultas Keguruan dan Ilmu Pendidikan

Universitas Palangka Raya

Email:info@chem.upr.ac.id Web:www.chem-upr.education/ojs

menjadi $(\mathrm{BB})^{1}$ disebabkan karena sisa kesulitan memberikan alasan yang benar, hal dijelaskan pada Tabel 12.

Tabel 12. Distribusi Pasangan Jawaban- Alasan Siswa Untuk Butir Soal PKPP

\begin{tabular}{|c|c|c|c|c|c|c|c|c|c|}
\hline \multirow[t]{2}{*}{ No } & \multirow{2}{*}{$\begin{array}{l}\text { Kunci } \\
\text { Jawa- } \\
\text { ban }\end{array}$} & \multicolumn{2}{|l|}{$\begin{array}{l}\text { Jumlah } \\
\text { Siswa }\end{array}$} & \multirow[t]{2}{*}{$\begin{array}{l}\text { Pilihan } \\
\text { Alasan }\end{array}$} & \multirow[t]{2}{*}{ No } & \multirow[t]{2}{*}{$\begin{array}{l}\text { Kunci } \\
\text { Jawaban }\end{array}$} & \multicolumn{2}{|l|}{$\begin{array}{l}\text { Jumlah } \\
\text { Siswa }\end{array}$} & \multirow[t]{2}{*}{$\begin{array}{l}\text { Pilihan } \\
\text { Alasan }\end{array}$} \\
\hline & & $\begin{array}{l}\mathrm{BT}^{1} \\
(\mathrm{BB})^{1}\end{array}$ & $\begin{array}{l}\mathrm{BT}^{2} \\
(\mathrm{BB})^{2}\end{array}$ & & & & $\begin{array}{l}\mathrm{BT}^{1} \\
(\mathrm{BB})^{1}\end{array}$ & $\begin{array}{l}\mathrm{BT}^{2} \\
(\mathrm{BB})^{2}\end{array}$ & \\
\hline \multirow[t]{4}{*}{1} & $\mathrm{C} 1$ & $\begin{array}{l}70.3 \\
(22.9)\end{array}$ & $\begin{array}{l}31.14 \\
(32.52)\end{array}$ & $1 *$ & 6 & A3 & $\begin{array}{l}65.1 \\
(42.9)\end{array}$ & $\begin{array}{l}10.3 \\
(7.45)\end{array}$ & 1 \\
\hline & & & $\begin{array}{l}8.0 \\
(6.50)\end{array}$ & 2 & & & & $\begin{array}{l}13.7 \\
(10.08)\end{array}$ & 2 \\
\hline & & & $\begin{array}{l}12.60 \\
(8.94)\end{array}$ & 3 & & & & $\begin{array}{l}53.43 \\
(65.78)\end{array}$ & $3^{*}$ \\
\hline & & & $\begin{array}{l}48.29 \\
(52.03)\end{array}$ & 4 & & & & $\begin{array}{l}22.6 \\
(16.66)\end{array}$ & 4 \\
\hline \multirow[t]{4}{*}{2} & A3 & $\begin{array}{l}78.57 \\
(53.42)\end{array}$ & $\begin{array}{l}8.6 \\
(8.00)\end{array}$ & 1 & 7 & B3 & $\begin{array}{l}79.4 \\
(55.4)\end{array}$ & $\begin{array}{l}8.6 \\
(4.31)\end{array}$ & 1 \\
\hline & & & & 2 & & & & $\begin{array}{l}9.1 \\
(8.27)\end{array}$ & 2 \\
\hline & & & $\begin{array}{l}63.7 \\
(68.36)\end{array}$ & $3^{*}$ & & & & $\begin{array}{l}63.1 \\
(53.95)\end{array}$ & $3^{*}$ \\
\hline & & & $\begin{array}{l}19.4 \\
(17.48)\end{array}$ & 4 & & & & $\begin{array}{l}19.1 \\
(13.66)\end{array}$ & 4 \\
\hline \multirow[t]{4}{*}{3} & B4 & $\begin{array}{l}68.6 \\
(42.0)\end{array}$ & $\begin{array}{l}32.3 \\
(4.66)\end{array}$ & 1 & 8 & A1 & $\begin{array}{l}68.6 \\
(23.4)\end{array}$ & $\begin{array}{l}32.2 \\
(34.16)\end{array}$ & $1^{*}$ \\
\hline & & & & 2 & & & & $\begin{array}{l}6.00 \\
(33.33)\end{array}$ & 2 \\
\hline & & & $\begin{array}{l}10.6 \\
(26.84)\end{array}$ & 3 & & & & $\begin{array}{l}10.6 \\
(7.50)\end{array}$ & 3 \\
\hline & & & $\begin{array}{l}51.1 \\
(57.19)\end{array}$ & $4^{*}$ & & & & $\begin{array}{l}51.1 \\
(55.01)\end{array}$ & 4 \\
\hline \multirow[t]{4}{*}{4} & A4 & $\begin{array}{l}74.3 \\
(42.3)\end{array}$ & $\begin{array}{l}6.6 \\
(5.00)\end{array}$ & 1 & 9 & B3 & $\begin{array}{l}56.6 \\
(38.8)\end{array}$ & $\begin{array}{l}20.9 \\
(4.04)\end{array}$ & 1 \\
\hline & & & $\begin{array}{l}13.4 \\
(11.92)\end{array}$ & 2 & & & & $\begin{array}{l}15.1 \\
(12.62)\end{array}$ & 2 \\
\hline & & & $\begin{array}{l}30.3 \\
(26.15)\end{array}$ & 3 & & & & $\begin{array}{l}52.6 \\
(67.67)\end{array}$ & $3^{*}$ \\
\hline & & & $\begin{array}{l}49.7 \\
(56.92)\end{array}$ & $4^{*}$ & & & & $\begin{array}{l}11.4 \\
(10.60)\end{array}$ & 4 \\
\hline \multirow[t]{4}{*}{5} & A3 & $\begin{array}{l}46.00 \\
(33.71)\end{array}$ & $\begin{array}{l}22.57 \\
(8.07)\end{array}$ & 1 & 10 & B4 & $\begin{array}{l}66.00 \\
(44.3)\end{array}$ & $\begin{array}{l}20.6 \\
(15.15)\end{array}$ & 1 \\
\hline & & & $\begin{array}{l}19.14 \\
(2.48)\end{array}$ & 2 & & & & $\begin{array}{l}10.00 \\
(5.62)\end{array}$ & 2 \\
\hline & & & $\begin{array}{l}46.86 \\
(73.29)\end{array}$ & $3^{*}$ & & & & $\begin{array}{l}12.3 \\
(12.12)\end{array}$ & 3 \\
\hline & & & $\begin{array}{l}12.57 \\
(9.93)\end{array}$ & 4 & & & & $\begin{array}{l}57.1 \\
(67.09)\end{array}$ & $4^{*}$ \\
\hline
\end{tabular}


Berdasarkan tabel di atas dapat ditentukan tingkat kesulitan pada yang terjadi pada siswa. Tingkat kesulitan ditentukan dengan data siswa yang memilih jawaban benar dengan pilihan alasan benar $(\mathrm{BB})^{1}$. Urutan tingkat kesulitan dari soal yang paling sulit ke soal yang mudah adalah nomor 1 , nomor 8 , nomor 5 , nomor 9 , nomor 3 , nomor 4 , nomor 6 , nomor 10 , nomor 2 , dan 7 .

\section{Kesimpulan}

Berdasarkan hasil penelitian dan pembahasan, maka dapat diambil beberapa kesimpulan, yaitu:

1. Sebagian besar siswa mengalami kesulitan memahami konsep pereaksi pembatas ditinjau dari level mikroskopis dan level makroskopis.

2. Urutan kesulitan (pada level makroskopis berdasarkan indikator adalah menentukan pereaksi pembatas dalam suatu reaksi jika diketahui masa dari masing-masing pereaksi (55,71\%); menentukan pereaksi pembatas dalam suatu reaksi jika gambar semua pereaksi dalam bentuk molekul gas $(67.00 \%)$; menentukan pereaksi pembatas dalam suatu reaksi jika diketahui mol dari masing-masing pereaksi $(69,14 \%)$; menentukan pereaksi pembatas dalam suatu reaksi jika gambar pereaksi dalam bentuk unsur dan molekul gas $(77,14 \%)$.

3. Urutan kesulitan pada level mikroskopis berdasarkan indikator adalah menentukan pereaksi pembatas dalam suatu reaksi jika gambar pereaksi dalam bentuk molekul gas (44,57\%); menentukan pereaksi pembatas dalam suatu reaksi jika gambar pereaksi dalam bentuk unsur dan molekul gas $(54,09 \%)$.

4. Siswa mengalami kesulitan dalam memahami konsep pereaksi pembatas kareana adanya pemahaman yang salah (miskonsepsi) mengenai pengertian pereaksi pembatas. Siswa menganggap pereaksi pembatas adalah; (a) pereaksi yang mempunyai koefisien reaksi terkecil; (b) pereaksi yang mempunyai koefisien reaski terbesar, (c) pereaksi yang mempunyai jumlah mol kecil (tidak melibatkan koefisien reaksi); dan (d) Pereaksi yang mempunyai massa lebih kecil.

\section{Saran}

Berdasarkan hasil penelitian, pembahasan dan kesimpulan, maka saran yang dapat diajukan adalah:

1. Guru perlu melakukan diagnosis terhadap kesulitan siswa dalam upaya meningkatkan kualitas pembelajaran, misalnya dengan mengembangkan bentuk soal disertai pemberian alasan seperti yang digunakan dalam TPKPP. 
2. Berdasarkan hasil penelitian ini sebaiknya dikembangkan strategi pembelajaran yang dapat mengatasi kesulitan tentang pereaksi pembatas.

\section{Daftar Pustaka}

Arifin, Mulyati. 1995. Pengembangan Program Pengajaran Bidang Studi Kimia. Airlangga Universiti Press : Surabaya.

Badan Standar Nasional Pendidikan (BSNP), 2008. Penetapan Kriteria Ketuntasan Minimal (KKM). Dirjen. PSMA Kemendiknas : Jakarta.

Herron, J. Dudley, 1985. Mathematics in the chemistry classroom. Journal of Chemical Education, vol. 62. Taylor \& Francis Ltd. : London.

Middlecamp, Chaterine dan Kean Elizabeth. 1985. Panduan Belajar Kimia Dasar. Gramedia : Jakarta.

Ozmen, Haluk. 2011. Turkish Primary students' conception about the particulate nature of matter. International Journal Of Environmmental \& Science Education. Vol 6, 99-121. http://www.ijese.com/ IJESE_v6n1_Ozmen.pdf diunduh tanggal 28 November 2011.

Purba, Michael. 2006. Kimia untuk SMA Kelas X. Erlangga: Jakarta.

Ningsih, Sri Wahyu, et al. 2013. Kimia SMA/MA Kelas X. Bumi Akasara Jakarta.

Kitti, 1996.. Intan Pariwara : Jakarta.

Achmad, Hiskia. 1986. Buku Materi Pokok Kimia Dasar. Karunika : Jakarta.

Winarni. 2007. Kimia untuk SMA dan MA Kelas X. Satu Buku : Jakarta.

Sidauruk, Suandi, 1995. Kesulitan Siswa SMA Memahami Konsep-konsep Ilmu Kimia. Tesis PPS-IKIP Jakarta : Jakarta.

Sidauruk, Suandi, 1998. Miskonsepsi siswa dalam memahami Stoikiometri, Makalah-tidak diterbitkan- Seminar Hasil-hasil Penelitian MIPA Murni dan Pendidikan, FKIP UNPAR : Palangkaraya.

Sidauruk, Suandi, 2005. Miskonsepsi Stoikiometri Pada Siswa SMA, DisertasiPEP, Program Pascasarjana Universitas Negeri Yogyakarta: Yogyakarta.

Somantri, Sutjihati. 2005. Psikologi Anak Luar Biasa. Refika Aditama : Bandung.

Sudyana, I. N. 2006. Pengaruh Model Pembelajaran Melalui Seting Belajar Kooperatif Terhadap Pemahaman Konseptual dan Pemahaman Algoritmik Kimia Siswa Sekolah Menengah Atas. Disertasi-Tidak diterbitkanUniversitas Negeri Malang : Malang.

Arikunto, Suharsimi. 2010. Prosedur Penelitian Suatu Pendekatan Praktik, Rineka Cipta ; Jakarta

Pangganti, Esdi. 2012. Kesulitan Siswa Kelas XII IPA SMA Negeri se Kabupaten Barito Utara Dalam Memahami redoks dan Elektrokimia. Tesis Program Pasca Sarjana Universitas Palangka Raya : Palangka Raya.

Sulistiyorini, Ari. 2012. Kesulitan Siswa SMP Memahami Konsep Partikel Materi. Tesis Program Pasca Sarjana Universitas Palangka Raya : Palangka Raya.

Sudijono, Anas, 2011. Pengantar Evaluasi Pendidikan. Raja Grafindo Persada : Jakarta. 
Jurnal Ilmiah Kanderang Tingang 9(2) (2018) 114-132 ISSN 2087-166X

Januari-Juni 2010
Fakultas Keguruan dan Ilmu Pendidikan

Universitas Palangka Raya

Email:info@chem.upr.ac.id Web:www.chem-upr.education/ojs

Azwar, Saifuddin, 2012. Repiabilitas dan Validitas. Pustaka Pelajar: Yogyakarta.

Sirhan G, 2007. Learning Difficululties in Chemistri: An Overview, Jurnal of Turkish Science Education Volume 4. Palestina: Turkish Science Education. 